\title{
Sources of Stress for Teachers Working in Private Elementary Schools and Methods of Coping with Stress*
}

\author{
Bahri Aydin", Ayça Kaya** \\ Department of Educational Science, Faculty of Education, University of Abant İzzet Baysal, Turkey \\ *Corresponding Author: bahriaydin@hotmail.com*, ayca.bagmen@hotmail.com**
}

Copyright $\bigcirc 2016$ by authors, all rights reserved. Authors agree that this article remains permanently open access under the terms of the Creative Commons Attribution License 4.0 International License

\begin{abstract}
The aim of this study is to determine the sources of stress for classroom teacher and branch teachers working in private elementary schools and methods that are used by them in order to cope with the stress. In this research, qualitative and quantitative methods have been used jointly. The group consisted of 258 private elementary school teachers working in Sakarya in 2015-2016 educational year. The study group of qualitative research consisted of 25 teachers working in private elementary schools in Sakarya province. The data collection tool for quantitative research is 'The scale of determining organizational stress sources and methods of coping with stress' that is developed by Doğan[11]. The analysis has been done through SPSS 23 for Windows; standard deviation mean, variance analysis, Kruskal-Wallis test and the U test of Mann Whitney have been used. The data collection tool for quantitative study is the semi-structured interview form prepared by the researchers. To analyze the data, techniques of content analysis and descriptive analysis have been used. According to findings obtained from quantitative data, reasons of stress for teachers are originated from school administration, the teaching profession and school facilities. According to findings obtained from qualitative data, issues that teachers are experiencing stress had been determined as; inadequacy of resources, constant supervision, the boredom and exhaustion of the profession, competition and ambition, irresponsible/problematic behaviors of students, high demands and expectations and not being able to spare time for themselves and etc. According to findings acquired both from qualitative and quantitative data, methods of coping with stress for teachers are; looking at things from positive side, spending time with beloved ones and creating an environment to spend time with them.
\end{abstract}

Keywords Private Elementary School, Classroom Teacher, Branch Teacher, Sources of Stress, Coping with Stress

\section{Introduction}

The stress, which has become a societal problem today, has become almost a part of our daily lives [24]. Stress is a phenomenon that has an impact on people and affecting their behaviors, their job performances and communication with their co-workers. Selye defines stress as an undetermined reaction demonstrated by physique against pressure [4]. According to Allen [1], the stress, regardless of giving or not giving pleasure or pain, signifies a non-special reaction of the body toward any request implied on it for its adaptation[8]. With a general definition, stress is a physiological and psychological reaction of an individual toward him/herself and external environment as a result of being affected by involved environment and working conditions. Stress does not occur automatically. It is developed by the effect of the transformations occurred in individuals' environment [12]. Due to several reasons such as educational policies that are constantly changing in our country, difficulties in the implication, deficiencies in physical conditions, inadequacy of the conditions that teachers are experiencing, teachers proceed to working under intense stress. Especially, it is seen that different factors are included in stress resources of teachers working in private elementary schools. Expectation of parents, demands of the administration, factors preventing to reveal the problems experienced with students, anxiety of dismissal from school also have a huge impact on teacher having a stress [25]. The first thing that comes to mind about stress is that is a negative feeling [1]. A teacher under stress might experience several health problems. Undoubtedly, one of the most affected parties of this situation will be students. According to Naylor [20], teachers with high level of stress, along with spreading negative vibes, are negatively affecting communication and interaction; causing negative behavior in student that might be permanent by making reckless mistakes. Along with that, administrative pressures observed in private schools frequently, might be the source of stress for teachers [22]. Mistakes resulting from unjust behavior in evaluations and time pressure based upon workload might cause irremediable damages in school environment by causing huge stress for 
teachers.

\subsection{Stress and Sources of Stress for Teachers}

If the teacher is in a stressful environment, her/his efficiency might decrease and this might be reflected upon the student and even for the whole society negatively [27]. This shows that it is possible for the same situation to be perceived differently by different people[28]. According to Turna[27], different sources of stress affecting the teacher are; demotivated students, time pressure, workload, disciplinary environment, coping with novelty, being evaluated by others, problems with co-workers, status, administrative reasons, conflict of duties and inappropriate working conditions. According to a research conducted in the United States of America (U.S.A.), sources of stress for teachers are; workload, relationship between teacher-administration, the structure of group, relationship with co-workers and occupational illiteracy[28]. According to Ertekin [13], however, sources of stress for teachers are indicated as; administrative support, monetary security, occupational problems and disciplinary problems of students. Pehlivan [22] had classified sources of stress in terms if; educational system, administrators and supervisors, student and job-related sources. On the other hand, Y1lmaztürk[29] had examined sources of stress for teachers under different categories and these are facilities of school and supervision, school administration, the teaching profession, colleagues, students and intervention of parents. When Manthei, Gilmore, Tuck and Adair [18] had examined the stress experienced by teachers, it is observed that high level of stress causes low job-fulfilment and, in the long run, low commitment. Undoubtedly, sources of stress stated in the literature may not have the same impact on every teacher. However, these sources of stress might cause different problems and affect the school environment negatively by expending gradually. That's why attempts for providing teachers to realize reasons for streets and methods for coping with the stress should be enhanced.

\subsection{Methods of Coping with Stress (Stress Management)}

The purpose of coping with stress or, in other words, stress management is not avoiding stress completely [16], but is to create an optimal, middle level stress [23]. The base of coping with stress is the transformation of though system of the individual and individual's negative ideas that are not accurate [6]. When the stress management is handled in educational organizations; it becomes important to find a way to decrease stress level in educational environment in line with perspectives of students, teachers and families. Few of attempts on this matter are; (i) transforming educational system, (ii) changing attitude toward students and personnel, (iii) changing emotional state in similar situations, (iv) changing perspective toward incidents and ( $v$ ) gaining an ability to communicate between people [2]. According to Pehlivan [23], techniques that can be used against stress are managing time with; physical and breathing exercises, meditation, biological feedback, relaxation, nutrition, social support, participation to social, cultural and sport activities, massage, praying and worshipping. According to Baştuğ [8], the outcomes of inefficiency of the teacher working in stressful environment might be reflected upon students, co-workers, families and steadily to the whole society. In this sense, it is important to know sources of stress for teachers that are causing stress most in order to intervene with those sources. Additionally, revealing how teachers will cope with the stress might enable to develop solutions in order to initiate the effects of stress.

\section{Purpose of Study}

The main concern of this study is to determine sources of stress and methods that are used to cope with the stress for teachers working in private schools that are among educational organizations exist in educational system. In this sense, sub-problems below had been sought for answers: For classroom and branch teachers working in private elementary schools, what are the sources of stress originating from facilities of school and supervision of school, teaching profession, colleagues, students, intervention of parents and individual reasons? Depending on age, gender, educational status, field of study, professional seniority, working time at school and marital status, is there a significant difference between stress levels caused by facilities of school and supervision of school, teaching profession, colleagues, students and intervention of parents? What are the methods of coping with stress? It is expected that this study and its findings will be a base for determination of factors causing a stress, professionally, for teacher working in private elementary schools and removal of those factors.

\section{Method}

In this study screening model one of the quantitative methods and qualitative method of case study were used.

\subsection{Study Group}

This research was conducted on a study group. The group consisted of 258 private elementary school teachers working in Sakarya in 2015-2016 educational year. It is observed that 167 of teachers $(64,7 \%)$ are women, while, 91 of them $(35,3 \%)$ are men; 134 of them are classroom teachers $(51,9 \%)$, while, 124 of them $(48,1 \%)$ are branch teachers; 126 of them $(48,8 \%)$ are at the age between $31-40$, while, 28 of them $(10,9 \%)$ are at the age 51 and above. The study group of this research, in which one the purposive sampling method in qualitative study methods of easily accessible sampling method had been used, consisted of teachers working in four (4) different private elementary schools in Adapazarı district of Sakarya province in 
educational year of 2015-2016. 25 teachers had participated in the research. When demographical characteristics of teachers employed in private elementary schools are examined, related information about participants had been reached; 20 of the participants are women $(80 \%)$ while 5 of them are men $(20 \%), 16$ of the participant are classroom teachers $(64 \%)$ while, 9 of them are branch teachers $(36 \%)$.

\subsection{Data Collection Tool}

The quantitative data collection tool of the study is 'the scale of determining organizational stress sources and methods of coping with stress' that is developed by Doğan[11]. The scale consisted of 3 parts while, the first part is constituted of demographic information. In the second part, questions that will reveal sources of stress for teachers are apparent while, in the third part, questions about methods of coping with stress. The scale of sources of stress for teachers consisted of 33 items, 5 point Likert scale from 1 to 5 and 6 subscales. These subscales are; facilities of school and supervision, school administration, teaching profession, colleagues, d-students and intervention of parents. The Cronbach's Alpha coefficient of the original scale was ,91 while it was calculated as, 84 in this study. These values demonstrate that the reliability of the scale is high. The scale of methods of coping with stress for teachers consists of 12 items and 5 point Likert scale. Cronbach's Alpha coefficient of the original scale was ,78 while it was ,53 in this study. This value demonstrates that the reliability of measurement tool is not low. In the research, semi-structured interview form developed by the researcher had been used as qualitative data collection tool. While the form was being developed, related literature had been scanned in detail; plenty of questionnaires related with stress had been revised and school administrators, academicians who are expert on the subject and teacher working in private elementary schools had been asked for an advice along with searching thesis, articles, books and other resources. As a result of the investigation of experts and pre-application that had been conducted, the form is finalized in a way serving to its purpose understandable and applicable by re-arranging items in the interview form, making attachments in missing parts and making related arrangements in items. Questions that appear in the form in accordance with the purpose of the research; (i) What are sources of stress affecting your life at school? In other words, what are situations causing you to be stressful? (related with facilities of school, school administration, teaching profession, colleagues, students and parents. Please indicate other circumstances other than this titles?), (ii) What do you do in order to cope with the stress? Which methods do you use?

\subsection{Data Collection}

Within the scope of quantitative research, for the implementation of the scale, written permission from the Provincial Directorate of National Education in Sakarya province and in order to conduct interviews within the scope of qualitative study, necessary permission from related departments of schools were obtained. Implications had been planned entirely on the basis of volunteering. Implication of the scope had been done in March, 2016 while interviews had been conducted in year 2015 between November-December.

\subsection{Analysis of Data}

Analysis of quantitative study had been done by using the software program SPSS 23; standard deviation, mean, variance analysis, Kruskal-Wallis test and the U test of Mann Whitney had been used. The significance analysis of data had been tested in .05 significance level. Values of arithmetic mean $(\overline{\mathrm{X}})$ and standard deviation $(\mathrm{S})$ regarding first and third sub-problems of the study had been founded. Non- parametrical tests of Kruskal-Wallis and Mann Whitney $U$ test regarding second sub-problem of the research had been used. In qualitative study, content analysis had been used in data analysis. Research questions had been examined in title form; subjects had been reached within the scope of questions. In order to categorize opinions of interviewees into subjects, similar, different and relational connections of comments had been taking into consideration regarding obtained data. How often comments had been mentioned (the frequency) was founded and data had been digitized. The purpose of digitating data is; increase the reliability, enabling to make comparison between categories and decrease the bias [26]. This is expected as implications increasing validity and reliability of research data. After the data analysis; whether findings are consistent, meaningful and in line with previously done theoretical framework, had been checked. This control had contributed to the research in terms of providing internal validity. After the interviews, the researcher had questioned whether his perception about the interview is reflecting the transferred data accurately by making summarization to participants what the researcher had comprehended and had provided external reliability. Subjects and codes had been sent to experts in order to confirm the final draft. For testing reliability, the formula of Miles and Huberman[19] (Reliability = Agreement $/$ Agreement + Disagreement $* 100)$ had been used. The codification of two training administrators, who are expert on the subject, had been compared and the coherence had been calculated as 90 percent. Since the percentage of coherence is perceived as adequate with 70 percent and above, reliability in terms of data analysis had been provided. Since anonymity of participants' identities had been regarded as appropriate ethically, while the findings are presented, classifications of teachers by using short-cuts, T1, T2... T25 had been done. Additionally, schools that teachers are employed had been represented in form of A, B, C, D. 


\section{Findings}

In this part, data obtained from teachers are presented in the form of tables.

\subsection{Findings Regarding First Sub-Problem}

Findings of Quantitative Study: In this part, data obtained from teachers have been presented in table form. For causing a stress for teachers working in private elementary schools; mean and standard deviation values regarding the stress level resulted from facilities of schools, school administration, teaching profession, colleagues, students and intervention of parents, had been demonstrated in Table 1.

Table 1. Mean and Standard Deviation Values Regarding Sub-Dimension of Sources of Stress for Teachers

\begin{tabular}{lcc}
\hline Sources of Stress & $\overline{\mathrm{X}}$ & S.S. \\
\hline School Facilities and Supervision & 17,65 & 4,717 \\
\hline School Administration & 33,74 & 4,850 \\
\hline Teaching Profession & 19,98 & 3,981 \\
\hline Colleagues & 13,60 & 3,323 \\
\hline Students & 16,50 & 3,813 \\
\hline Intervention of Parents & 12,46 & 1,933 \\
\hline Overall & 113,93 & 14,013 \\
\hline
\end{tabular}

When Table 1 is examined, it has been observed that; sources of stress in sub-dimension of Facilities of School and Supervision is moderate $(\bar{X}=17,65)$, sources of stress in sub-dimension of school administration is high $(\bar{X}=33,74)$, sources of stress in sub-dimension of teaching profession is moderate $(\bar{X}=19,98)$, sources stress in sub-dimension of colleagues is high $(\bar{X}=13,60)$, sources of stress in sub-dimension of students is moderate $(\bar{X}=16,50)$, sources of stress in sub-dimension of intervention of parents is high $(\bar{X}=12,46)$, average sources of stress is in high level ( $\bar{X}=113,93$ ). When opinions of participants have been examined, it is observed that issues that teachers experience stress most are school administration, teaching profession and facilities of school/supervision.

Findings of Qualitative Study: First question that appear in the form aimed to determine what sources of stress affecting teachers are; "'What are sources of stress affecting you in your school life? In other words; what are circumstances causing you to be stressful? as an answer for these questions, teachers had stated their opinions regarding matters based upon facilities of school, school administration, teaching profession, colleagues, students, parents, educational system and personal reasons. In Table 2, opinions of teachers appear regarding sources of stress affecting teachers.

Table 2. Findings Regarding Sources of Stress Effecting Teachers

\begin{tabular}{|c|c|}
\hline Subject & Codes and Frequency (f) \\
\hline $\begin{array}{l}\text { Originating from } \\
\text { School Facilities }\end{array}$ & $\begin{array}{l}\text { Lack of Resources ( } \mathrm{f}=16 \text { ), Lack of Technological Facilities ( } \mathrm{f}=14) \text {, Lack of Space ( } \mathrm{f}=13 \text { ), Long Working Hours ( } \mathrm{f}=12 \text { ), } \\
\text { Size of the School Building }(\mathrm{f}=16) \text {, Transportation Difficulties ( } \mathrm{f}=7 \text { ), Heating problems of School Building ( } \mathrm{f}=4) \text {, Dining } \\
\text { Problems ( } \mathrm{f}=2 \text { ) Overall }(\mathrm{f}=76)\end{array}$ \\
\hline $\begin{array}{l}\text { Originating from } \\
\text { Colleagues }\end{array}$ & $\begin{array}{l}\text { Competition and Ambition ( } \mathrm{f}=22) \text {, Widespread Gossiping }(\mathrm{f}=19) \text {, Shifting Duties }(\mathrm{f}=17) \text {, Having Conflicts }(\mathrm{f}=12) \text {, Lack } \\
\text { of Support }(\mathrm{f}=8) \text { Overall }(\mathrm{f}=78)\end{array}$ \\
\hline $\begin{array}{l}\text { Originating from } \\
\text { School } \\
\text { Administration }\end{array}$ & $\begin{array}{l}\text { Constant Supervision }(\mathrm{f}=21) \text {, Lack of Encouragement }(\mathrm{f}=20) \text {, Excessive Workload ( } \mathrm{f}=19) \text {, Attitudes }(\mathrm{f}=18) \text {, Constant } \\
\text { Changes in Practices }(\mathrm{f}=17) \text {, Time Pressure }(\mathrm{f}=15) \text {, Assignments }(\mathrm{f}=15) \text {, Disagreeing with Decisions }(\mathrm{f}=12) \text {, Intervention } \\
\text { with Teachers }(\mathrm{f}=11) \text {, Duty Intense Course Load }(\mathrm{f}=9) \text {, Working outside the working hours }(\mathrm{f}=6) \text {, Intimidation Policies } \\
(\mathrm{f}=5) \text {, Shifting System }(\mathrm{f}=4) \text {, Problems with exercising legal rights }(\mathrm{f}=2) \text {, Lack of Educational Opportunities }(\mathrm{f}=1) \\
\text { Overall ( } \mathrm{f}=158)\end{array}$ \\
\hline $\begin{array}{l}\text { Originating from } \\
\text { Students }\end{array}$ & $\begin{array}{l}\text { Undisciplined/Problematic Behaviors ( } \mathrm{f}=24) \text {, Academic Incompetence ( } \mathrm{f}=21) \text {, Being Unprepared/Irresponsibility ( } \mathrm{f}=15) \text {, } \\
\text { Indifference ( } \mathrm{f}=12) \text { Overall }(\mathrm{f}=72)\end{array}$ \\
\hline $\begin{array}{l}\text { Originating from } \\
\text { Teaching Profession }\end{array}$ & $\begin{array}{l}\text { Exhausting and Boring Nature of the profession ( } \mathrm{f}=18 \text { ), Being responsible to many people ( } \mathrm{f}=16 \text { ), Low social status } \\
(\mathrm{f}=15) \text {, Remuneration policies }(\mathrm{f}=12) \text {, Obligation of Preparing the Curriculum }(\mathrm{f}=11) \text {, Constantly Changing Educational } \\
\text { System }(\mathrm{f}=7) \text {, Lack of Promotional Opportunities }(\mathrm{f}=5) \quad \text { Overall }(\mathrm{f}=84)\end{array}$ \\
\hline $\begin{array}{l}\text { Originating from } \\
\text { Parents }\end{array}$ & $\begin{array}{l}\text { High Demands and Expectations ( }(\mathrm{f}=25) \text {, Intervening with Teachers' duties ( } \mathrm{f}=23) \text {, Informing out of working hours ( } \mathrm{f}=22) \text {, } \\
\text { Accusing the teacher }(\mathrm{f}=18) \text {, Fulfilling Students' responsibilities }(\mathrm{f}=15) \text {, Indifference }(\mathrm{f}=7) \text { Overall }(\mathrm{f}=110)\end{array}$ \\
\hline $\begin{array}{l}\text { Originating from } \\
\text { Personal Reasons }\end{array}$ & 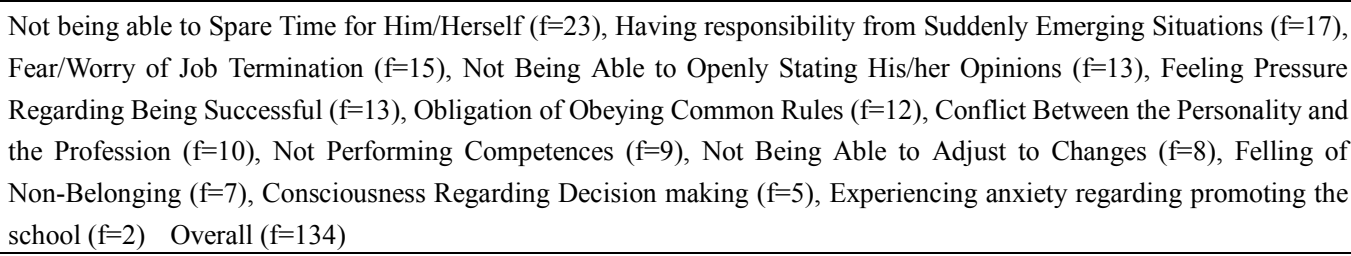 \\
\hline
\end{tabular}


When Table 2 is examined, teachers working in private elementary schools had stated that stress primarily originated from school administration ( $\mathrm{f}=158)$. It is followed by personal reasons $(\mathrm{f}=134)$, parents $(\mathrm{f}=110)$, teaching profession $(\mathrm{f}=84)$, colleagues $(\mathrm{f}=78)$, facilities of school $(\mathrm{f}=76)$ and students $(\mathrm{f}=72)$.

Among the codes that are formed correlatively with the theme of stress originated from facilities of school, most repeated opinions had been seen as lack of resources $(f=16)$, lack of technological facilities $(\mathrm{f}=14)$ and lack of space $(\mathrm{f}=13)$. For example; "We are having difficulty having photocopy whenever we desire. There is a daily quota. Every time we have a photocopy, we put our names and signatures. This causes a tension for us" (A-T1).

Among the codes that are formed correlatively with the theme of stress originated from school administration, most repeated ones are constant supervision $(\mathrm{f}=21)$, lack in encouragement $(\mathrm{f}=20)$ and work overload $(\mathrm{f}=20)$. For example; "Constant inquiring of the principal and not creating free space, making me feel like being constantly monitored, cause a stress for me." (D-T25).

Among the codes that are formed correlatively with the theme of stress originating from teaching profession, most repeated opinions are; boring and exhausting nature of the profession ( $\mathrm{f}=18)$, being responsible to many people $(\mathrm{f}=16)$ and low social status $(\mathrm{f}=25)$. For example; "The profession itself can be exhausting and, from time to time, boring. The job that I performed can be intimidating at some point." (A-T5).

Among the codes that are formed correlatively with the theme of stress originating from colleagues, most repeated opinions have been observed as; competition and ambition $(\mathrm{f}=22)$, widespread gossiping ( $\mathrm{f}=19$ ) and shirking the duty $(\mathrm{f}=17)$. For example; "There is a pointless competition among teachers. Formation of the competition around concepts such as status, financial situation etc., however, not around the profession or success, creating a stress in working environment. Even though staying away from that kind of conflicts considering the personality, indirectly, you feel a negative energy on yourself." (A-T21).

Among the codes that are formed correlatively with the theme of stress originating from students, most highlighted ones are mentioned as; undisciplined/problematic behaviors $(\mathrm{f}=24)$, academic incompetency $(\mathrm{f}=21)$ and being unprepared / irresponsibility $(\mathrm{f}=15)$. For example; "There are students having adaptation problems related with school. These students who are violating rules and agreements made in the class, causing me to have stress." (D-T12).

Among the codes that are formed correlatively with the theme of stress originating from parents, most highlighted ones are; high demands and expectation $(\mathrm{f}=25)$, intervening in teacher's work $(\mathrm{f}=23)$ and asking for information out of working hours $(\mathrm{f}=22)$. For example; "The perception about paid education widespread among parents, is reflected upon educational quality and us. The attitude of the parents as if the educational system only centered around their children is quite oppressive." (A-T21).

When opinions highlighted within the theme of stress originating from personal reasons, the most repeated opinions are observed as; not being able to spare time for him/herself $(\mathrm{f}=23)$, taking a responsibility in situations emerging suddenly $(\mathrm{f}=17)$ and concern/fear of job termination $(\mathrm{f}=15)$. For example; "Due to business in the school life, I cannot allocate time for anything. After leaving the school, I can neither go to bank nor bazaar. I feel very exhausted when I arrive home and I do not have any energy left to do something." (A-T8).

\subsection{Findings Regarding Second Sub-problem (Quantitative Findings)}

Depending on demographic variables of teacher working in private elementary schools; whether there is a significant difference between stress level originating from sub-dimensions of sources of stress, have been demonstrated in Table 3 .

Table 3. Results of Mann-Whitney U test in respect to Differentiation of Opinions About Sub-dimensions of Sources of Stress in Accordance with Demographic Variables

\begin{tabular}{cccccc}
\hline The Scale & $\begin{array}{c}\text { The } \\
\text { Variable }\end{array}$ & $\overline{\mathrm{X}}$ & $\begin{array}{c}\text { Sum of } \\
\text { the } \\
\text { Column }\end{array}$ & $\mathrm{U}$ & $\mathrm{p}$ \\
\hline $\begin{array}{c}\text { Classroom } \\
\text { Intervention of } \\
\text { Parents }\end{array}$ & $\begin{array}{c}\text { Teacher } \\
\text { Branch } \\
\text { Teacher }\end{array}$ & 140,77 & 18863,50 & 6797,50 & $0,011^{*}$ \\
\hline $\begin{array}{c}\text { School } \\
\text { Administration }\end{array}$ & Female & 138,49 & 23127,00 & & \\
\hline Male & 113,01 & 10284,00 & 6098,00 & $0,009^{*}$ \\
\hline $\begin{array}{c}\text { Colleagues } \\
\text { Parents }\end{array}$ & $\begin{array}{c}\text { Female } \\
\text { Male }\end{array}$ & $\begin{array}{c}144,17 \\
102,58\end{array}$ & $\begin{array}{c}24076,50 \\
9334,50\end{array}$ & 5148,50 & $0,000^{*}$ \\
\hline $\begin{array}{c}\text { Intervention of } \\
\text { Male }\end{array}$ & $\begin{array}{c}\text { Female } \\
138,26\end{array}$ & 23089,50 \\
13,42 & 10321,50 & 6135,50 & $0,010^{*}$ \\
\hline
\end{tabular}

${ }^{*} p<0,05$

According to Table 3; in terms of stress level originating from intervention of parents, there is a significant difference between classroom and branch teachers $(\mathrm{U}=6797,50$, $\mathrm{p}<0,05)$. It is observed that stress levels of classroom teachers originating from intervention of parents are higher than the stress level of branch teachers. The stress level originating from intervention of parents demonstrate a significant difference depending on the gender $(U=6135,50$, $p<0,05)$. The stress level in female teachers originating from intervention of parents is higher than male teachers. There is a significant difference between stress levels in female and male teachers originating from school administration $(\mathrm{U}=6098,00, p<0,05)$. The stress level in female teachers resulting from school administration is higher than male teachers. The stress level originating from colleagues demonstrate a significant difference depending on gender $(\mathrm{U}=5148,50, p<0,05)$. The stress level in female teacher originating from colleagues is higher than male teachers. 
Table 4. Results of Kruskal-Wallis Test in respect to Differentiation of Sources of Stress Depending on the Dimension of School Facilities and Supervision

\begin{tabular}{|c|c|c|c|c|c|c|}
\hline \multirow{12}{*}{$\begin{array}{c}\text { School } \\
\text { Facilities } \\
\text { and } \\
\text { Supervision }\end{array}$} & $\begin{array}{c}\text { Professional } \\
\text { Seniority }\end{array}$ & $\mathbf{N}$ & $\begin{array}{l}\text { Mean of } \\
\text { Column }\end{array}$ & sd & $\chi^{2}$ & $\mathbf{p}$ \\
\hline & $\begin{array}{c}1-5 \text { years and } \\
\text { above }\end{array}$ & 45 & 139,00 & \multirow{5}{*}{1,26} & \multirow{5}{*}{12,984} & \multirow{5}{*}{0,011 * } \\
\hline & $6-10$ years & 59 & 141,32 & & & \\
\hline & $11-15$ years & 79 & 112,69 & & & \\
\hline & $16-20$ years & 41 & 112,02 & & & \\
\hline & $\begin{array}{l}21 \text { years and } \\
\text { above }\end{array}$ & 34 & 156,54 & & & \\
\hline & $\begin{array}{c}\text { Period of } \\
\text { Working in } \\
\text { School } \\
\end{array}$ & $\mathbf{N}$ & $\begin{array}{l}\text { Mean of } \\
\text { Column }\end{array}$ & sd & $\chi^{2}$ & $\mathbf{p}$ \\
\hline & $\begin{array}{l}1-3 \text { years } \\
4-6 \text { years }\end{array}$ & 109 & 145,63 & \multirow{5}{*}{1,27} & \multirow{5}{*}{15,861} & \multirow{5}{*}{0,003 * } \\
\hline & $\begin{array}{l}\text { 4-6 years } \\
7-9 \text { years }\end{array}$ & 51 & 132,72 & & & \\
\hline & $\begin{array}{c}7-9 \text { years } \\
10-12 \text { years }\end{array}$ & 53 & 104,97 & & & \\
\hline & 12 vears an & 28 & 99,84 & & & \\
\hline & $\begin{array}{l}12 \text { years and } \\
\text { above }\end{array}$ & 17 & 141,76 & & & \\
\hline
\end{tabular}

$* p<0,05$

Findings related with outcomes of Kruskal-Wallis test that is regarding differentiation of sources of stress depending on sub-dimensions of facilities of school and supervision, are presented in Table 4.
According to Table 4, in terms of stress level originating from school facilities and supervision, there is a significant difference regarding professional seniority $\left(\mathrm{X}^{2}=12,984\right.$ $p<0,05)$. The stress level of teachers working for 21 years and above, is higher than other teachers with different seniority levels. Additionally, the stress level originating from school facilities and supervision demonstrate a significant difference depending on working period in the school $\left(\mathrm{X}^{2}=15,861 p<0,05\right)$. The stress level in teachers with working period of 1-5 years is higher than other teachers. Stress levels originating from school facilities and supervision, teaching profession, students, intervention of parents, school administration and colleagues do not demonstrate a significant difference in terms of gender, educational field, age, educational status and marital status $(p>0,05)$.

\subsection{Findings Regarding Third Sub-Problem}

Findings of Quantitative Research: Analysis regarding methods of coping with stress is demonstrated in Table 5.

Table 5. Mean and Standard Deviation Values of Opinions in respect to Methods of Coping with Stress

\begin{tabular}{|c|c|c|c|c|c|c|c|c|}
\hline \multirow{3}{*}{$\begin{array}{l}\text { Entries } \\
\text { 4. I spend time with my beloved ones in situations that I } \\
\text { feel stressful }\end{array}$} & \multicolumn{2}{|c|}{ Never } & \multirow{2}{*}{$\begin{array}{c}\text { Seldom } \\
11\end{array}$} & \multirow{2}{*}{$\frac{\text { Sometimes }}{55}$} & \multirow{2}{*}{$\begin{array}{c}\text { Usually } \\
91\end{array}$} & \multirow{2}{*}{$\begin{array}{c}\text { Always } \\
96\end{array}$} & \multirow{3}{*}{$\overline{\mathrm{X}}$} & \multirow{3}{*}{$\begin{array}{l}\text { S.S. } \\
0,966\end{array}$} \\
\hline & $\mathrm{f}$ & 5 & & & & & & \\
\hline & $\%$ & 1,9 & 4,3 & 21,3 & 35,3 & 37,2 & & \\
\hline \multirow{2}{*}{$\begin{array}{l}\text { 3. In order to deal with my stress, I positively talk with } \\
\text { myself (I look things from positive side) }\end{array}$} & $\mathrm{f}$ & 2 & 20 & 55 & 89 & 92 & \multirow{2}{*}{3,97} & \multirow{2}{*}{0,976} \\
\hline & $\%$ & 0,8 & 7,8 & 21,3 & 34,5 & 35,6 & & \\
\hline \multirow{2}{*}{$\begin{array}{l}\text { 1. I create an environment to cope with my stress in } \\
\text { situation that I feel stressful }\end{array}$} & $\mathrm{f}$ & 3 & 20 & 54 & 109 & 72 & \multirow{2}{*}{3,88} & \multirow{2}{*}{0,945} \\
\hline & $\%$ & 1,2 & 7,8 & 20,9 & 42,2 & 27,9 & & \\
\hline \multirow{2}{*}{ 2. I avoid situations reminding things causing a stress } & $\mathrm{f}$ & 3 & 11 & 71 & 136 & 37 & \multirow{2}{*}{3,75} & \multirow{2}{*}{0,795} \\
\hline & $\%$ & 1,2 & 4,3 & 27,5 & 52,7 & 14,3 & & \\
\hline \multirow{2}{*}{$\begin{array}{l}\text { 9. I share the situation causing a stress with people I } \\
\text { have trusted in order to cope with my stress }\end{array}$} & $\mathrm{f}$ & 5 & 29 & 74 & 105 & 45 & \multirow{2}{*}{3,6} & \multirow{2}{*}{0,966} \\
\hline & $\%$ & 1,9 & 11,2 & 28,7 & 40,7 & 17,5 & & \\
\hline \multirow{2}{*}{$\begin{array}{l}\text { 11. I spare time for my hobbies in situation that feel } \\
\text { stressful }\end{array}$} & $\mathrm{f}$ & 8 & 30 & 72 & 111 & 37 & \multirow{2}{*}{3,54} & \multirow{2}{*}{0,979} \\
\hline & $\%$ & 3,1 & 11,6 & 27,9 & 43 & 14,4 & & \\
\hline \multirow{2}{*}{$\begin{array}{l}\text { 7. I plan the job I want to perform ahead of time in order } \\
\text { to manage time better in situation that I feel stressful. }\end{array}$} & $\mathrm{f}$ & 11 & 57 & 64 & 86 & 40 & \multirow{2}{*}{3,34} & \multirow{2}{*}{1,112} \\
\hline & $\%$ & 4,3 & 22,1 & 24,8 & 33,3 & 15,5 & & \\
\hline \multirow{2}{*}{$\begin{array}{l}\text { 12. I confront with the person causing a stress in order } \\
\text { to cope with my stress }\end{array}$} & $\mathrm{f}$ & 16 & 53 & 67 & 95 & 27 & \multirow{2}{*}{3,25} & \multirow{2}{*}{1,088} \\
\hline & $\%$ & 6,2 & 20,5 & 26 & 36,8 & 10,5 & & \\
\hline \multirow{2}{*}{ 5. I do sport in situations that I feel stressful } & $\mathrm{f}$ & 48 & 74 & 55 & 48 & 33 & \multirow{2}{*}{2,78} & \multirow{2}{*}{1,299} \\
\hline & $\%$ & 18,6 & 28,7 & 21,3 & 18,6 & 12,8 & & \\
\hline 10. In order to cope with my stress, I use relaxation & $\mathrm{f}$ & 47 & 75 & 66 & 57 & 13 & & \\
\hline $\begin{array}{l}\text { methods (meditation yoga, muscle relaxation, deep } \\
\text { breathing exercises) }\end{array}$ & $\%$ & 18,2 & 29,1 & 25,6 & 22,1 & 5 & 2,67 & 1,156 \\
\hline 6 Inray in situation that I feel stresful & $\mathrm{f}$ & 37 & 90 & 78 & 35 & 18 & 264 & 1101 \\
\hline o. 1 pray in situation that 1 leer stressiul & $\%$ & 14,3 & 34,9 & 30,2 & 13,6 & 7 & 2,04 & 1,101 \\
\hline 8. I receive support from experts in order to cope with & $\mathrm{f}$ & 85 & 75 & 63 & 31 & 4 & 220 & 1076 \\
\hline my stress. & $\%$ & 32,9 & 29,1 & 24,4 & 12,0 & 1,6 & 2,20 & $1,0 / 0$ \\
\hline & & & Ger & Average & & & & \\
\hline
\end{tabular}


According to Table 5; it appears that perception level regarding "Methods of Coping with Stress" is in high level $($ General average $=3,30)$. When averages of items are examined, the item of "I receive help from experts in order to cope with my stress" $(\bar{X}=2,20)$ has the lowest perception, while, "I pray in situations when I am stressful" $(\bar{X}=2,64)$ is the second lowest and "I use several relaxation methods in order to cope with my stress" $(\bar{X}=267)$ is the third lowest item. When items with highest perception are examined, it is observed that; the article of "I spend time with my beloved ones situations in which I am stressful" ( $\bar{X}=4,02)$ has the highest perception, while, the items of "I talk with myself positively in order to cope with my stress" $(\overline{\mathrm{X}}=3,97)$ is the second highest and the items of "I create an environment in order to cope with my stress in situations that I am stressful" $(\bar{X}=3,88)$ is the third highest item.

Findings of Qualitative Study: The second question appear in the form in order to determine sources of stress affecting teachers is as follows; "What do you do in order to cope with the stress? Which methods do you use?". In Table 6 , opinions of teachers regarding methods of coping with stress are presented.

Table 6. Findings Regarding Methods of Coping with Stress for Teachers

\begin{tabular}{clc}
\hline The Theme & Codes & Frequency (f) \\
\hline & Looking things from positive side & 13 \\
& Spending time with beloved ones & 12 \\
& Creating an environment & 11 \\
Methods & Talking with people who he/she trusted & 11 \\
of Coping & Sparing time for hobbies & 9 \\
with Stress & Using relaxation techniques & 8 \\
for & Forgetting reasons for stress & 7 \\
Teachers & Confronting with the person causing a stress & 5 \\
& Praying & 3 \\
& Receiving help from experts & 2 \\
& Doing physical exercises & 2 \\
\hline
\end{tabular}

Among the codes that are formed correlatively with methods of coping with stress for teachers working in private elementary schools, most highlighted ones have been observed as; looking things from a positive side $(\mathrm{f}=13)$, spending time with beloved ones $(\mathrm{f}=12)$, creating an environment $(\mathrm{f}=11)$ and talking with people whom they trusted ( $\mathrm{f}=11$ ). For example; "I act like a Pollyanna. I try to see the positive sides of things by analyzing them." (A-T1); "I make plans with friend of mine that I adore. I spend time with him/her." (B-T24); "The most pleasant one is creating an environment. Since we do not have the chance to remain silent in the environment and being excluded from the environment, joining different environments after school makes me feel good." (C-T7); "I make a judgment related with current situation. That means I do best that I can; However, I bring up this matter to someone I trust. When I talk about the topic, I think that she / he understands it." (B-T14).

\section{Results, Conclusions and Recommendations}

According to findings obtained from qualitative research, issues which teachers have gone through stress most are originating from school administration, teaching profession and school facilities. Additionally, it is observed that among methods of coping with stress, most preferred ones are spending time with beloved ones, looking things at bright side and creating an environment. According to findings obtained from qualitative research, issues that teachers experience stress are; originating from school facilities (lack of resources, lack of technological facilities etc.); originating from school administration(constant supervision, lack of encouragement etc.); originating from teaching profession (exhausting and boring nature of the profession, low social status and etc.); originating from colleagues (rivalry and ambition, widespread gossiping etc.); originating from students (undisciplined/problematic behaviors, academic incompetence etc. ); originating from parents (high demands and expectations, intervening with the teacher's duties etc.) and originating from personal reasons (not being able to spare time for him/herself, fear of job termination etc.). Methods of coping with stress for teachers are looking things from positive side, spending time with beloved ones and creating an environment with them, talking with people whom they trust, spending time for hobbies, using relaxation techniques, forgetting reasons for stress. In the research, finding of qualitative and quantitative studies are in line with each other. It is possible to make these interpretations with reference to having common characteristics in terms of dimensions.

According to participants' opinions, sources of stress affecting teachers originating from school facilities; lack of resources and technological facilities, lack of space, long working hours, big-small size of the school building, transformational difficulties, heating conditions of school building and eating problems. It is though provoking that even though teachers are working in private schools, they experience problems regarding resources and technological equipment. At the same time, in schools with financial concerns, having great numbers of students in small classrooms, the quality of education decreases. Argon and Ateş had determined stress factors affecting teachers as; crowded classrooms, disciplinary problems, problematic behaviors and aggressive attitudes of students, continuous changes in programs, conflicts with colleagues, insufficient administrative support [4]. Issues that teachers experience stress originating from school administration; constant supervision, lack of encouragement, excessive workload, unjust manners, constant changes in practices, time pressure, work assignments, disagreeing with decisions, intervention with teacher's duty, intensity of course load, working outside of working hours, policies of intimidation, shifting system, problems of exercising legal rights and lack in educational opportunities. Additionally, it is observed that the stress level in female teachers originating from school administration is 
significantly higher than male teachers. It is remarkable that among sources of stress for teachers working in private elementary school, mostly highlighted ones are originating from school administration. In this case, it can be said that administrators create intense pressure on teachers and have a big impact on creating a stress for teachers. Unjust approach of administration and pursuing discriminatory policies may also cause as stress for teachers. Whether the hard work is praised by doing what is necessary or determination of evaluation terms depending on biased relationships may cause a stress for teachers by raising doubts. According to research outcomes of Başbuğ[8], one of the sources of stress that teachers experience stress most are administrative reasons. According to findings of this research, the leading issues causing stress for teachers are administrative. According to opinions of participants, sources of stress affecting teachers due to teaching profession are boring and exhausting nature of the profession, being responsible to many people, low social status, remuneration policies, obligation of curriculum preparation, constantly changing educational system and few possibilities for promotion. Majority of teachers, had stated that the profession is exhausting and boring both mentally and physically than other professions the teaching profession has a vital importance in raising work force necessary for the society because teachers spend most of their times by dedicating themselves to their professions. This situation causes a stress for teachers working quite hard despite not having enough prestige in society. Besides not having economically satisfactory remuneration, teachers demonstrate great effort regardless of many difficulties of the profession. In exchange of all these efforts, while promotion opportunities are limited teachers had been forced to keep up with constantly changing educational system. All of those are factors for teachers to experience stress. Akpinar [3], stated that sources of stress affecting teachers negatively are disciplinary problems, pressure originating from time, low remuneration and social status and excessive work load. Issues that teachers experience stress originating from colleagues are competition and ambition, widespread gossiping, shirking duties, having discords and not receiving support. When it is considered that research had been conducted in private school, those results are not surprising. Because, it is accepted from the teacher to have different characteristics compare to other co-workers in order to pursue their work and be able to remain within the organization that they work. Unavoidably, this might transform into rivalry, conflict and some ambitions among teachers. As a result of teachers' efforts for proving his/her own professional competence and abilities, not being willing to take a responsibility for colleagues who demonstrate free riding and perceiving them as rivals, may trigger stress. According to results of the research conducted by Göksoy and Argon; teachers experience stress originating from social relations, school environment, bureaucratic structure and the profession itself. According to participants' opinions, sources of stress affecting teachers due to students are disciplinary/problematic behaviors, academic incompetence, being unprepared/ irresponsibility and indifference. Along with innovations brought by globalizing world, alterations in student profiles had occurred. Especially, it is possible for students getting education in private schools to have high expectations from teachers. Along with those, spoiled attitudes of students toward teachers and accepting students as right in many situations by administration and parents damage teacher's authority and cause teacher to have stress. Turna[27] stated that one of the reasons that creates stress for classroom teachers is indifference of students toward classes. Issues that teachers experience stress originating from parents are; high demands and expectations, intervening with the teacher's duties, asking for information out of working hours, accusing the teacher, fulfilling students' duties and indifference. Additionally, it is observed that the stress level of classroom teacher originating from intervention of parents is higher than branch teachers; the stress level of female teacher is higher than male teachers. Increasing expectation of parents, perceiving that they have the right to have directly intervention in school and class might cause an intense stress for teachers. Because, when teachers do not have autonomy, they might have problems both professionally and personally. Unthoughtful approach of parents as if teachers do not have a life outside the school and their constant demands for being informed might intimidate teachers. Perceiving other students or teachers as sources of problems by disregarding problems of their children and approaching a matter with accusatory approach toward teachers increases sources of stress for teachers. In his research, Bertan [9] had founded that unjust demands of parents creates significant stress on school administrators; similarly, Kömoğ [17] had founded that one of stress factors for teachers is parents. According to participants opinions; sources of stress affecting teachers due to personal reasons are; not being able to spare time for themselves, having a responsibility on suddenly merging situations, fear/worry of job termination, not being able to openly state their opinions, feeling pressure to be successful, obligation to obey common rules, conflict between personal nature and he profession, not performing competences, not being able to adjust to changes, feeling of non-belonging, consciousness regarding decision making and experiencing anxiety regarding promoting the school. One of the issues that teachers experience stress most is the problem of mixing of personal and professional life. A teacher who is responsible to many people in school life, even though she/he leaves the school, might continue to think about matters related with school. For teachers, who are not able to spare time to his/her personal matters (bank, hospital and etc.), experiencing a stress is unavoidable. Along with that, due to reasons such as some responsibilities necessitated by working in private school, constantly expanding expectation of the administration and parents, teachers might be personally unwilling to perform their professions. According to Bakırc1 [7], sources of stress that causing the stress most are; decrease of quality in educational system and for teachers, having less authority and more responsibility; the 
sources of stress causing a stress least is perception of teachers regarding their professional incompetence. According to participants' opinions, methods used by teachers in order to cope with stress are looking things from a positive side, spending time with beloved ones, creating an environment, talking with people who they trust, sparing time for hobbies, using relaxation techniques, forgetting reasons of stress, confronting with the person causing the stress, praying receiving help from experts and doing physical activities. In both research methods (qualitative and quantitative) for teachers working in private schools, the most preferred methods of coping with stress are looking things from positive side and spending time with beloved ones; the least preferred ones are receiving help from experts and praying. This situation might raise thoughts regarding that teachers give importance to positive thinking while having difficulty receiving help from experts. In the research conducted by Doğan [11], it is stated that most preferred methods of coping with stress by classroom teachers are; spending time with beloved ones, having positive dialogues and creating an environment in order to cope with stress. According to Turna[27], it is observed that preferences are made in terms of spending time with beloved ones, looking things from a positive side and avoiding situations causing a stress in order to cope with stress. These findings coincide with findings of this research completely. Çetin and Kuru [10] had stated that students experiencing stress show tendencies to receive help from their families and friends. As a result, stress is perceived as a phenomenon that can be felt in almost every situation in today's conditions. It is observed that people who spend most of their time in workplace are exposed to experience stress. [21]. It should be known that stress always exists, however, as long as being aware of its existence and knowing how to deal with it, it is beneficial for people [15].

In light of all these information, due to environmental conditions, it is possible for teachers to experience a constant stress. Resultantly, it is important to make improvements and arrangements for teachers raising individuals who are part pf the society and preparing them for future in order to minimize negative impacts of the stress. Regarding responses related with sources of stress and methods of coping with stress, it can be suggested that arranging seminars in the context of developing methods for coping with stress personally and professionally, regarding teachers working in private elementary schools, implementation of supervision done in schools with the perspective of guiding and career development; improving remuneration of teacher in order them to reach certain living standards, making regulations regarding prevention of employment of teacher with lower remuneration compare to counterparts working in public schools, rising the status of teaching profession, providing an education within the organization regarding behaviors and human interactions toward prevention of negative situations such as conflicts, rumors and rivalry among teachers; providing parents with parental guide book containing organizational information of school in order to minimize the stress originating from parents and arranging trainings for parents. A similar study can be conducted with teachers working in public school and comparison between two groups in terms of sources of stress can be done.

\section{Note}

*The abstract of this paper was presented at 2nd International Conference on Lifelong Learning and Leadership for All (ICLEL-16), in Liepaja on July, 21-23, 2016.

\section{REFERENCES}

[1] Allen, R. (1983). Human stress: its nature and control. New York: McMillan Publishing Company.

[2] Abac1, R. (1997). Methods of coping with stress in the school. Ondokuz Mayıs University, Journal of Education Faculty 10(1), 7-22.

[3] Akpınar, B. (2008). Opinions of teachers regarding causes of stress for teachers during educational process. Kastamonu Journal of Education, 16(2), 359-366.

[4] Aksoy, A. and Kutluca, F. (2005). A research about sources of stress in work life, symptoms of stress and investigation of outcomes of stress. Journal of Social Politics Conferences (49).

[5] Argon, T. and Ateş, H. (2007). Stress factors affecting teachers of first grade in elementary school. AIHU, Journal of Education Faculty, 7(2), 53-63.

[6] Aydın, B. and İmamoğlu, S. (2001). Group study aimed to develop skills for coping with stress. M.U. Atatürk Education Faculty, Educational Sciences Journal, Year: 2001, Issue 14, Pages: 41-52

[7] Bakırc1, B. (2012). What are the organizational sources of stress affecting teachers working in secondary education organizations? (The case of Edirne province). Master Thesis, Trakya University, Retrieved from: http://tez2.yok.gov.tr/

[8] Baştuğ, A. (2009). Situation of being affected by administrator's behaviors creating a stress for teachers working in secondary education organizations. Master Thesis, Kırıkkale University, Kırıkkale. Retrieved from http://tez2.yok.gov.tr/

[9] Bertan, B. (2012). The correlation between organizational stress experienced by school administrators working in public-private elementary schools and their organizational commitments (The case of Pendik). Master Thesis, Yeditepe University, İstanbul. Retrieved from http://tez2.yok.gov.tr/.

[10] Çetin, Ç. Ç. and Kuru, E. (2010). Investigation of styles of coping with stress of students of physical education and sports in terms of some variables. National Education, Issue 187, pages:193-206.

[11] Doğan, F. (2008). Sources of stress for homeroom teachers and methods of coping. Master Thesis, Gazi University Ankara. Retrieved from http://tez2.yok.gov.tr/. 
[12] Eren, E. (2008). Organizational behavior and psychology of management. İstanbul: Beta Publishing Company.

[13] Ertekin, Y. (1993). Stress and Administration. TODAİE Publishing, Ankara, page 149.

[14] Göksoy, S. and Argon, T. (2014). Inhibitory and Supportive sources of stress for teachers in schools. Journal of Teacher Education and Educators, Volume 3, Issue 2, 245-271.

[15] Karagül, M. (2011). Organizational stress and stress management: the case of Malatya courthouse: Balıkesir. Unpublished Master Thesis, Balıkesir University, Balıkesir.

[16] Kaya, M. D. and Keskin, G. (2008). Administrative sources of stress and level of tendencies to stress for managers: A research in Erzurum province. Atatürk University Social Sciences Institute Journal, 11(1).

[17] Kömoğ, M. (2009). Organizational sources of stress in educational organization and solutions: An application in educational organizations. Master Thesis, Beykent University, İstanbul. Retrieved from: http://tez2.yok.gov.tr/.

[18] Manthei, R., Gilmore, A., Tuck, B., and Adair, V. (1996). Teacher stress in intermediate schools. Educational Research, 38(1), 3-19.

[19] Miles, M. B. \& Huberman, A. M. (1994) Qualitative Data Analysis: an Expanded Sourcebook, Thousand Oaks, Calif., Sage.

[20] Naylor, C. (2001). Teacher workload and stress. BCTF Research Reports Section III.
[21] Örücü, E., Kılıç, R. and Ergül, A. (2011). Impact of the stress in individual performance in work life: a research regarding education and health workers. Journal of Akademik Bakış, 26, $1-21$.

[22] Pehlivan, İ. (1992). Organizational sources of stress and efficiency. Ankara University Journal of Faculty of Educational Sciences, 24(2), 791-802.

[23] Pehlivan, İ. (1994). Personal and organizational strategies for coping with stress. Ankara Ankara University Journal of Faculty of Educational Sciences, 27(2), 803-815.

[24] Sabuncuoğlu, Z. and Melek Tüz. (2003). Organizational psychology. Bursa: Furkan Publishing Company.

[25] Ünal, S. (1999). A correlation between sources of stress and efficiency in schools. M.U. Atatürk Education Faculty Journal of Educational Sciences, Issue: 11, Pages: 365-372.

[26] Yıldırım, A. and Şimşek, H. (2011). Quantitative research methods in social sciences (8. Print). Ankara: Seçkin.

[27] Turna, H. (2014). Stress resources and coping methods with stress for teachers (The example of Edirne province/Keșan. Master Thesis, Okan University, İstanbul. Retrieved from: http://tez2.yok.gov.tr/.

[28] Tutar, H. (2000). Management in crisis and stress environment. İstanbul: Hayat.

[29] Y1lmaztürk, A. (2013). Primary schools' managers' organizational stress sources and keys for solution (İstanbul city Sultanbeyli district sample). Master Thesis, Yeditepe University, İstanbul. Retrieved from: http://tez2.yok.gov.tr/. 